University of Nebraska - Lincoln

DigitalCommons@University of Nebraska - Lincoln

$3-9-2021$

\title{
Variations in bacterial community structure and antimicrobial resistance gene abundance in cattle manure and poultry litter
}

Biyensa Gurmessa

Amanda J. Ashworth

Yichao Yang

Mary Savin

Philip A. Moore Jr

See next page for additional authors

Follow this and additional works at: https://digitalcommons.unl.edu/usdaarsfacpub

Part of the Agriculture Commons

This Article is brought to you for free and open access by the U.S. Department of Agriculture: Agricultural Research Service, Lincoln, Nebraska at DigitalCommons@University of Nebraska - Lincoln. It has been accepted for inclusion in Publications from USDA-ARS / UNL Faculty by an authorized administrator of DigitalCommons@University of Nebraska - Lincoln. 


\section{Authors}

Biyensa Gurmessa, Amanda J. Ashworth, Yichao Yang, Mary Savin, Philip A. Moore Jr, Steven C. Ricke, Giuseppe Corti, Ester Foppa Pedretti, and Stefania Cocco 


\title{
Variations in bacterial community structure and antimicrobial resistance gene abundance in cattle manure and poultry litter
}

\author{
Biyensa Gurmessa ${ }^{\mathrm{a}}$, Amanda J. Ashworth ${ }^{\mathrm{b}, *}$, Yichao Yang ${ }^{\mathrm{c}}$, Mary Savin ${ }^{\mathrm{c}}$, Philip A. Moore Jr. ${ }^{\mathrm{b}}$, \\ Steven C. Ricke ${ }^{\mathrm{d}}$, Giuseppe Corti ${ }^{\mathrm{a}}$, Ester Foppa Pedretti ${ }^{\mathrm{a}}$, Stefania Cocco ${ }^{\mathrm{a}}$ \\ ${ }^{a}$ Department of Agriculture, Food and Environmental Sciences, Università Politecnica Delle Marche, Via Brecce Bianche 10, 60131, Ancona, Italy \\ ${ }^{\mathrm{b}}$ USDA-ARS, Poultry Production and Product Safety Research Unit, 1260 W. Maple St, Fayetteville, AR, 72701, USA \\ ${ }^{c}$ Department of Crop, Soil, and Environmental Sciences, University of Arkansas, 115 Plant Science Building, University of Arkansas, Fayetteville, AR, 72704 , USA \\ ${ }^{\mathrm{d}}$ Meat Science \& Animal Biologics Discovery Program (MSABD), Department of Animal and Dairy Sciences, University of Wisconsin-Madison, 1933 Observatory Drive, \\ Madison, WI, 53706, USA
}

\section{A R T I C L E I N F O}

\section{Keywords:}

Animal manure

Bacterial diversity

Total solid content

Heavy metals

Broiler litter

\begin{abstract}
A B S T R A C T
Cattle manure and poultry litter are widely used as fertilizers as they are excellent sources of nutrients; however, potential adverse environmental effects exist during land applications, due to the release of zoonotic bacteria and antimicrobial resistance (AMR) genes. This study was conducted to understand linkages between physiochemical composition, bacterial diversity, and AMR gene presence of cattle manure and poultry litter using quantitative polymerase chain reaction to enumerate four AMR genes ( $\mathrm{ermB}$, sulI, intlI, and $b a_{c t x-m-32}$ ), Illumina sequencing of the $16 \mathrm{~S}$ region, and analysis of physical and chemical properties. Principal coordinate analysis of Bray-Curtis distance revealed distinct bacterial community structures between the two manure sources. Greater alpha diversity occurred in cattle manure compared to poultry litter $(P<0.05)$. Redundancy analysis showed a strong relationship between manure physiochemical and composition and bacterial abundance, with positive relationships occurring among electrical conductivity and carbon/nitrogen, and negative associations for total solids and soluble fractions of heavy metals. Cattle manure exhibited greater abundance of macrolide (ermB) and sulfonamide (sull) resistant genes. Consequently, fresh cattle manure applications may result in greater potential spread of AMR genes to the soil-water environment (relative to poultry litter) and novel best management strategies (such as composting) may reduce the release of AMR genes to the soil-water environment.
\end{abstract}

\section{Introduction}

Manure land applications may pose environmental health risks, despite its role in improving soil fertility and organic matter, by serving as a pathway for the release of zoonotic bacteria and antibiotic resistance genes (ARGs) to the environment (Gurmessa et al., 2020; Xie et al., 2018; Ziemer et al., 2010). However, there is lack of knowledge on the link between manure properties and microbial composition and the abundance of ARGs. Disparities in manure physiochemical properties, such as moisture content, $\mathrm{pH}$, carbon to nitrogen $(\mathrm{C} / \mathrm{N})$ ratio, and nutrient composition (Zhou and Yao, 2020) may affect microbial composition and abundance (Xu et al., 2020). Trace element levels are also reportedly linked to bacterial community structure and ARGs, although specific relationships are largely unknown (Ding et al., 2017).

Animal manure is generally characterized as having high nitrogen
(N), phosphorus (P), and potassium (K) contents (Zhou and Yao, 2020). Specifically, $310 \mathrm{mg} \mathrm{kg}^{-1} \mathrm{P}$ (on dry matter basis) was reported for cattle manure (Giles and Cade-Menun, 2014), with approximately $1500 \mathrm{mg}$ $\mathrm{kg}^{-1} \mathrm{P}$ being reported for poultry litter (consists of a combination of bedding material, feces, and litter) (Ashworth et al., 2020). Manure pH also varies depending on the manure type. A neutral to sub-alkaline $\mathrm{pH}$ range (6.8-7.9) has been reported for cattle manure (Huang et al., 2017; Whalen et al., 2000), whereas an average $\mathrm{pH}$ of 8.12 is typical for poultry litter (Ashworth et al., 2020). However, it is unknown how physiochemical properties are related with microbial abundance.

Previous studies have reported a wide range of antimicrobial resistant (AMR) genes in manure and the most widely studied were genes resistant to tetracyclines (tet), sulfonamides (sul), macrolidesstreptogramin B (erm), mobile genetic elements (MGEs), and integrons (int) (Gurmessa et al., 2020). However, these resistance genes may not be found in all manure sources. A detailed investigation of AMR in three

\footnotetext{
* Corresponding author.

E-mail address: amanda.ashworth@usda.gov (A.J. Ashworth).
} 


\section{Abbreviations}

$\begin{array}{ll}\text { AMR } & \text { antimicrobial resistance } \\ \text { ARGs } & \text { antibiotic resistance genes } \\ \text { CM } & \text { cattle manure } \\ \text { LOQ } & \text { limit of quantification } \\ \text { MGEs } & \text { mobile genetic elements } \\ \text { PL } & \text { poultry litter } \\ \text { qPCR } & \text { quantitative polymerase chain reaction } \\ \text { TS } & \text { total solids } \\ \text { EC } & \text { electrical conductivity } \\ \text { C/N } & \text { carbon/nitrogen } \\ \text { ermB } & \text { erythromycin resistance gene } \\ \text { sulI } & \text { sulfonamide resistance gene } \\ \text { intlI } & \text { integrase gene } \\ \text { and blactx-m-32 } \beta \text {-Lactams resistance gene } \\ \text { Ct } & \text { cycle threshold }\end{array}$

manure sources (bovine, poultry, and swine) by Qian et al. (2018) revealed that about one-third of the 109 commonly found AMR genes were identified in cattle manure and poultry litter. In our experiment, the set of targets was chosen to cover clinically, environmentally, and agriculturally relevant antibiotic resistance determinants. The specific targets were chosen by a panel of scientists working on antibiotic resistance in agriculture, and they aligned with an environmental antibiotic resistance gene surveillance effort in Europe (Durso et al., 2012; Durso and Cook, 2014). The blaCTX-M gene codes for third-generation cephalosporin resistance, one type of $\beta$-lactamase resistant drug. The erm $B$ gene codes for resistance to macrolide drugs, such as erythromycin. The sul1 gene codes for sulfonamide-resistance and is one of the most commonly studied resistance genes in environmental samples. Finally, the intl1 gene codes for an integron-integrase gene that helps AR genes spread from cell to cell. These drugs are classified as "Critically Important" (the top category) by the World Health Organization and used in large and small animals, and is approved for use in cattle, swine, and poultry, and is administered to food animals via food and water (Durso et al., 2012; Durso and Cook, 2014).

Reduction of AMR genes in manure is essential to minimize the transfer and movement to the environment following land application. Although, it is largely unknown how microbial diversity and abundance of AMR genes vary based on manure source (fresh cattle manure and poultry litter) that are typically applied to pasture soils to improve fertility (Yang et al., 2019). In the study region, typical poultry litter handling procedures include aerating in-house windrows to increase the temperature and kill pathogens before land application, whereas cattle manure is deposited directly to pastures during grazing. Therefore, understanding the bacterial diversity and abundance of ARGs based on local practices and their possible linkage with physiochemical composition may assist in developing manure best management strategies.

It is important to evaluate microbial composition, diversity, and abundance along with AMR genes to employ a subsequent management approach that can be effective against reducing the transmission of AMR genes to the environment and improving soil health. However, data are lacking on the linkages between physiochemical properties, manure source, and bacterial diversity (Wang et al., 2016). Hence, the current study aimed at 1) investigating the abundance of bacterial community composition in cattle manure and poultry litter prior to land application via Illumina sequencing, 2) quantifying four AMR-associated genes in cattle manure and poultry litter via quantitative polymerase chain reaction (qPCR), and 3) identifying linkages between bacterial alpha diversity and physiochemical properties for two manure sources.

\section{Materials and methods}

\subsection{Cattle manure and poultry litter sampling}

In the spring of 2018 and 2019, 1-2 kg of poultry litter samples were collected from in-house piles gathered from a local typical broiler production system in Booneville, AR ( $\mathrm{n}=6$ per year, $\mathrm{n}=12$ total). Samples were collected from the center of in-house piles following 5-6 flocks (stored for up to four months), with bedding material, ventilation, and growth out days being representative of typical regional grower conditions (Ashworth et al., 2020). Following, typical cattle manure land application methods, fresh cattle (Angus crosses) manure was sampled at the United States Department of Agriculture, Agricultural Research Service, Dale Bumpers Small Farms Research Center (Pilon et al., 2019) during a grazing experiment (Yang et al., 2020) by collecting 1-2 kg of cattle manure following fresh deposition (within $24 \mathrm{~h} ; \mathrm{n}=7$ per year, $\mathrm{n}$ $=14$ total) in the spring of 2018 and 2019 and represents regional pasture management procedures. Care was taken not to contaminate samples by sterilizing sampling equipment with $70 \%$ ethanol, placed in a cooler for transport, and stored at $-80^{\circ} \mathrm{C}$ until DNA extraction.

\section{Manure chemical analysis}

Samples were analyzed for moisture content, $\mathrm{pH}$, EC, soluble metals, ammonium- $\mathrm{N}\left(\mathrm{NH}_{4}-\mathrm{N}\right)$, nitric- $\mathrm{N}\left(\mathrm{NO}_{3}-\mathrm{N}\right)$, and total $\mathrm{C}$ and $\mathrm{N}$ (TC and $\mathrm{TN}$ ). Moisture content was determined by oven drying a subsample at $65{ }^{\circ} \mathrm{C}$ for 1 week, and total solids (TS) content was determined as the percentage fraction of dry mass to fresh sample. Water soluble metals were extracted on fresh aliquots using a 1:10 solid:liquid extraction ratio (Self-Davis and Moore, 2000). A subsample of the water extract was used to measure $\mathrm{pH}$ and EC. $\mathrm{NH}_{4}-\mathrm{N}$ and $\mathrm{NO}_{3}-\mathrm{N}$ were extracted on fresh aliquots by $\mathrm{KCl} 1 \mathrm{M}$ solution using a 1:10 solid:liquid extraction ratio (Self-Davis and Moore, 2000). Soluble metals in the water extracts were analyzed by inductively coupled plasma optical emission spectroscopy (ICP-OES) on an Agilent 5110 ICP-OES (Agilent Technologies, Santa Clara, CA, USA). Both $\mathrm{NH}_{4}-\mathrm{N}$ and $\mathrm{NO}_{3}-\mathrm{N}$ were obtained colorimetrically on a Skalar auto-analyzer (Skalar, Buford, GA, USA), using the salicylate-nitroprusside USEPA Method 351.2 (1983) for $\mathrm{NH}_{4}-\mathrm{N}$ and the cadmium-reduction method according to APHA (1995) for $\mathrm{NO}_{3}-\mathrm{N}$. Total metals were determined by digesting oven-dried, ground litter samples with $70 \%$ nitric acid and $30 \%$ hydrogen peroxide according to the method by Zarcinas et al. (1987) followed by ICP-OES analysis. Total C and $\mathrm{N}$ were determined by dry combustion Elementar Vario Max Analyzer (Elementar Americas, Ronkonkoma, NY, USA).

\subsection{DNA extraction, PCR amplification, and sequencing}

DNA was extracted from manure and litter using the extraction kit MpBio FastDNA Spin Kit for Soil (MpBio Laboratories, SKU 116560200$\mathrm{CF}$ ) according to the manufacturer's directions. Extracted DNA was quantified using Quant-ItTM PicoGreen ${ }^{\circledR}$ (Invitrogen) dsDNA quantitation assay and stored at $20^{\circ} \mathrm{C}$. Samples were dried at $70^{\circ} \mathrm{C}$ for $48 \mathrm{~h}$ to determine gravimetric moisture content, which was used to present data per gram dry weight.

Bacterial community composition was determined using Illumina Miseq sequencing of $16 \mathrm{~S}$ rRNA gene amplicons. Extracted DNA was sent to the University of Tennessee Genomic Services Laboratory, where the $\mathrm{V} 4$ region of the $16 \mathrm{~S}$ rRNA gene was amplified with barcoded primers $515 \mathrm{~F}$ and $806 \mathrm{R}$ (Caporaso et al., 2011). Amplicon libraries were pooled, and 291 base-paired end sequences were obtained on the Illumina MiSeq Platform, resulting in a total of $2,136,829$ sequence reads. Reads were processed using the open source bioinformatics software Mothur V 1.40.0 following the Miseq protocol (Kozich et al., 2013). Sequences that did not match the primers were eliminated from demultiplexed sequence reads. These ambiguous base sequences with a length less than $100 \mathrm{bp}$ were deleted and chimeric sequences were removed using the 
Table 1

Physiochemical properties of cattle manure and poultry litter. Numbers in parentheses represent the standard deviations.

\begin{tabular}{|c|c|c|c|}
\hline Variable & $\mathrm{CM}^{\ddagger}, \mathrm{N}^{\mathrm{a}}=12$ & $\mathrm{PL}^{\neq}, \mathrm{N}^{\mathrm{a}}=14$ & p-value \\
\hline $\mathrm{pH}$ & $7.95(0.25)$ & $8.33(0.12)$ & $<0.001$ \\
\hline Total N (\%) & $3.14(0.70)$ & $4.23(0.44)$ & $<0.001$ \\
\hline Total C (\%) & $47.0(4.5)$ & $36.7(3.5)$ & $<0.001$ \\
\hline $\mathrm{C} / \mathrm{N}$ & $15.4(2.5)$ & $8.7(0.4)$ & $<0.001$ \\
\hline TS $(\%)^{¥}$ & $14(2)$ & $76(7)$ & $<0.001$ \\
\hline $\mathrm{EC}\left(\mathrm{dS} \mathrm{m}^{-1}\right)$ & $940(114)$ & $11(2)$ & $<0.001$ \\
\hline Mo $\left(\mathrm{mg} \mathrm{kg}^{-1}\right)$ & $<\mathrm{LOQ}$ & $2.00(1.39)$ & $<0.001$ \\
\hline $\mathrm{Mn}\left(\mathrm{mg} \mathrm{kg}^{-1}\right)$ & $9(5)$ & $21(4)$ & $<0.001$ \\
\hline Se $\left(\mathrm{mg} \mathrm{kg}^{-1}\right)$ & $<\mathrm{LOQ}$ & $0.33(0.15)$ & $<0.001$ \\
\hline $\mathrm{Ti}\left(\mathrm{mg} \mathrm{kg}^{-1}\right)$ & <LOQ) & $0.38(0.25)$ & $<0.001$ \\
\hline $\mathrm{Zn}\left(\mathrm{mg} \mathrm{kg}^{-1}\right)$ & $10(4)$ & 70 (19) & $<0.001$ \\
\hline $\mathrm{Ni}\left(\mathrm{mg} \mathrm{kg}^{-1}\right)$ & $1.52(0.41)$ & $5.00(1.19)$ & $<0.001$ \\
\hline $\mathrm{Pb}\left(\mathrm{mg} \mathrm{kg}^{-1}\right)$ & $<\mathrm{LOQ}$ & $0.035(0.025)$ & $<0.001$ \\
\hline As $\left(\mathrm{mg} \mathrm{kg}^{-1}\right)$ & $<\mathrm{LOQ}$ & $0.49(0.25)$ & $<0.001$ \\
\hline $\mathrm{Cd}\left(\mathrm{mg} \mathrm{kg}^{-1}\right)$ & $<\mathrm{LOQ}$ & $0.047(0.020)$ & $<0.001$ \\
\hline $\mathrm{Co}\left(\mathrm{mg} \mathrm{kg}^{-1}\right)$ & $<\mathrm{LOQ}$ & $0.59(0.15)$ & $<0.001$ \\
\hline $\mathrm{Cr}\left(\mathrm{mg} \mathrm{kg}^{-1}\right)$ & $0.50(0.67)$ & $0.28(0.10)$ & 0.5 \\
\hline $\mathrm{Cu}\left(\mathrm{mg} \mathrm{kg}^{-1}\right)$ & $3(1)$ & $64(41)$ & $<0.001$ \\
\hline $\mathrm{Fe}\left(\mathrm{mg} \mathrm{kg}^{-1}\right)$ & $20(9)$ & $83(42)$ & $<0.001$ \\
\hline $\mathrm{K}\left(\mathrm{g} \mathrm{kg}^{-1}\right)$ & $6(3)$ & $33(8)$ & $<0.001$ \\
\hline $\mathrm{Ca}\left(\mathrm{g} \mathrm{kg}^{-1}\right)$ & $1.91(0.97)$ & $2.06(1.7)$ & 0.7 \\
\hline $\mathrm{Mg}\left(\mathrm{g} \mathrm{kg}^{-1}\right)$ & $2.38(0.93)$ & $0.39(0.23)$ & $<0.001$ \\
\hline $\mathrm{P}\left(\mathrm{g} \mathrm{kg}^{-1}\right)$ & $1.77(0.91)$ & $1.40(0.73)$ & 0.2 \\
\hline $\mathrm{S}\left(\mathrm{g} \mathrm{kg}^{-1}\right)$ & $0.67(35)$ & $16(7.6)$ & $<0.001$ \\
\hline $\mathrm{NH}_{4}-\mathrm{N}\left(\mathrm{g} \mathrm{kg}^{-1}\right)$ & $0.76(0.4)$ & $5(0)$ & $<0.001$ \\
\hline $\mathrm{NO}_{3}-\mathrm{N}\left(\mathrm{mg} \mathrm{kg}^{-1}\right)$ & $<\mathrm{LOQ}$ & $449(256)$ & $<0.001$ \\
\hline
\end{tabular}

$\neq \mathrm{CM}=$ Cattle manure, $\mathrm{PL}^{\neq}=$poultry litter, $\mathrm{TS}^{¥}=$ total solids. $<\mathrm{LOQ}=$ below quantification limit.

Nutrients and trace elements concentrations are soluble fractions expressed on a dry matter basis.

a $\mathrm{N}=$ number of replicates.

b Statistical tests performed: Fisher's exact test; Wilcoxon rank-sum test.

UCHIME algorithm implemented in Mothur. After the quality control pipeline, 1,677,430 sequence reads remained using a $97 \%$ similarity threshold to define ribotypes in Mothur (21.49\% were deleted). Taxonomic assignment was performed using the Greengenes database. Microbial alpha diversity including Chao1, observed operational taxonomic unit (OTU), Shannon index, and Simpson index were calculated using Mothur. Beta-diversity was measured by using Bray-Curtis index, weighted and unweighted UniFrac distance metrics. Principal coordinate analysis (PCoA) plots were generated based on weighted and unweighted UniFrac distance metrics. Bacterial community structure was quantified in a matrix of Bray-Curtis similarities, which was then analyzed in a permutational analysis of variance (PERMANOVA) to compare bacterial communities at the phylum level in PRIMER-E.

Quantitative -PCR was performed to quantify these four AMR genes in the DNA extracts from cattle manure and poultry litter samples. Amplifications were performed in a QuantStudio ${ }^{\mathrm{TM}} 3$ Real-Time PCR system (ThermoFisher Scientific, Cat. A28137). Each $20 \mu \mathrm{L}$ Q-PCR reaction included $5 \mu \mathrm{L}$ of extracted DNA (approximately $100 \mathrm{ng}$ ) or standard, $10 \mu \mathrm{L}$ of SYBR Green PCR Master Mix, $1 \mu \mathrm{L}$ of $100 \mathrm{mM}$ of each primer and $3 \mu \mathrm{L}$ of distilled water. The positive control (named gBlock2 $4 \mathrm{G}$ with $16 \mathrm{~S} \mathrm{ermB}$ Florez 1-18-17) is an 808bp double stranded synthetic

Table 2

PERMANOVA for bacterial community structure of cattle manure and poultry litter.

\begin{tabular}{lll}
\hline Factor & Pseudo-F & $P$-value \\
\hline Animal source & 31.539 & $<0.001^{\mathrm{b}}$ \\
Year & 8.26 & $0.019^{\mathrm{a}}$ \\
Animal source x Year & 0.54 & 0.437 \\
\hline
\end{tabular}

${ }^{\text {a }}$ Statistically significant $(\alpha=0.05)$.

${ }^{\mathrm{b}}$ Statistically significant $(\alpha=0.01)$.
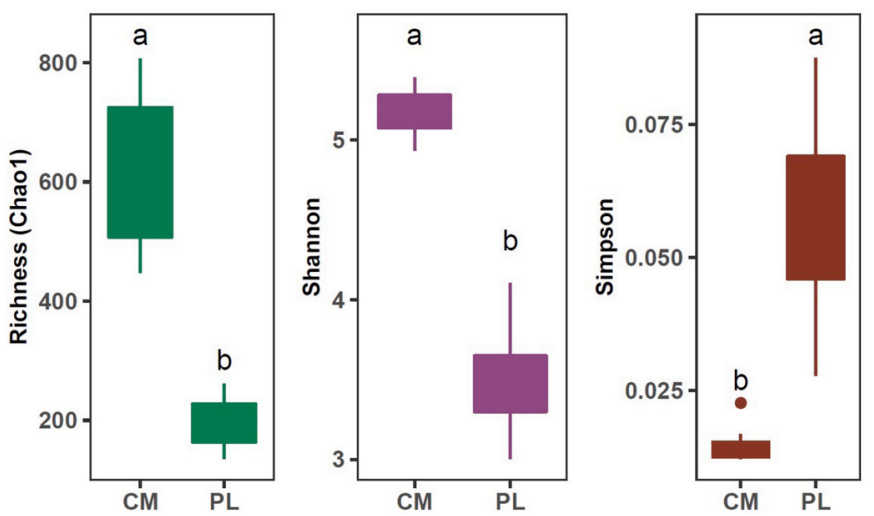

Fig. 2. Comparison of bacterial diversity indices of cattle manure (CM) and poultry litter (PL). A) Chao1, B) Simpson, and C) Shannon. Different letters reported on the bars indicate significant difference $(P<0.001)$.

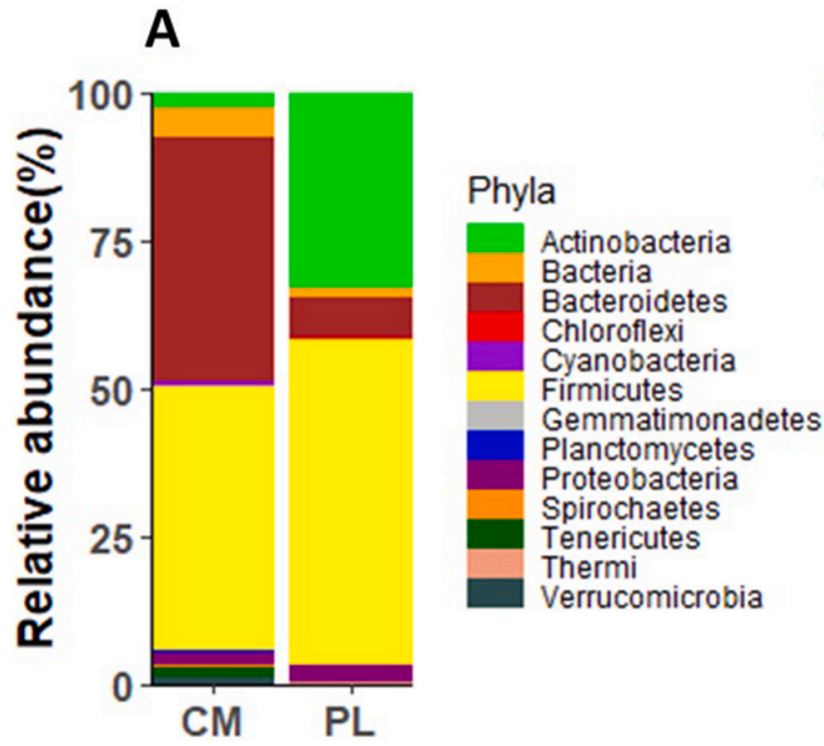

B

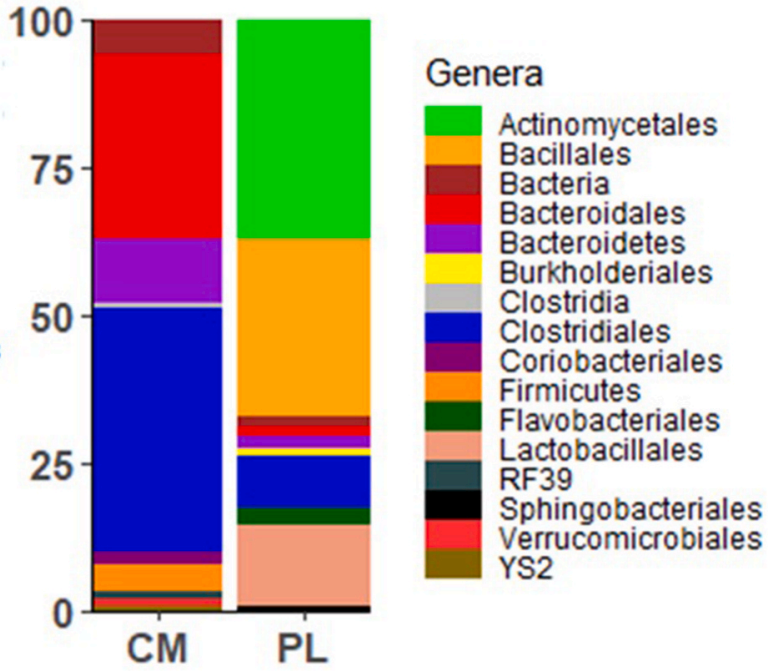

Fig. 1. Relative abundance of bacteria in cattle manure (CM) and poultry litter (PL) at phylum (A) and genus (B) levels. 


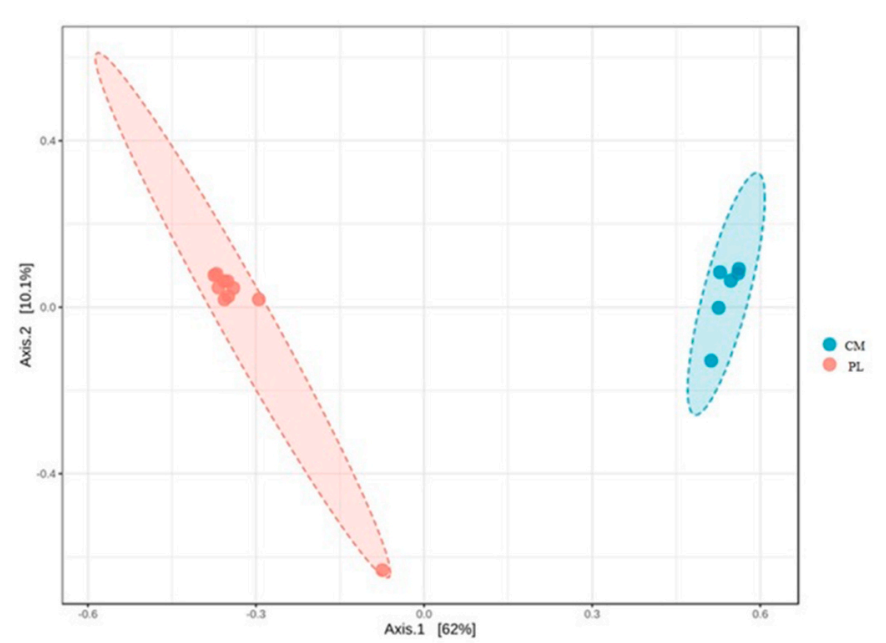

Fig. 3. Principal Coordinate Analysis (PCoA) of Bray-Curtis distances of bacterial community structure in cattle manure (CM) and poultry litter (PL).

gBlocks ${ }^{\circledR}$ gene fragment synthesized by Integrated DNA technologies, lnc. (Blazejewski et al., 2019). It contains four genes of ermB, sulI, intll, and $b l a_{c t x-m-32}$. The standard curves consisted of a serial dilution of known copy numbers of the gene fragment, ranging from $1.15 \times 10^{5}$ to $1.15 \times 10^{11}$ copies per $5 \mu$ l. The quantities of gene copy numbers were calculated based on the standard curve using Quant Studio 3 real-time PCR system. (ThermoFisher Scientific). As a negative control, all sets of primers were tested with sterile water as the template and all of them were below the threshold. Each reaction was technically replicated three times per extracted sample DNA and standard DNA, resulting in an average cycle threshold $(\mathrm{Ct})$ value used to estimate the initial quantity. The following cycling conditions were used: an initial denaturation step of $15 \mathrm{~min}$ at $95{ }^{\circ} \mathrm{C}$, followed by 40 cycles of $15 \mathrm{~s}$ at $95{ }^{\circ} \mathrm{C}, 30 \mathrm{~s}$ at annealing temperature specific for each gene, and $10 \mathrm{~s}$ at $72{ }^{\circ} \mathrm{C}$ followed by $60-95^{\circ} \mathrm{C}$ of melting curve.

The amplification efficiency was between $92 \%$ and $105 \%$, and the $\mathrm{R}^{2}$ value was above 0.98 . Baseline and threshold calculations were performed using QuantStudio ${ }^{\circledR}$ Design \& Analysis software. Gene copy abundances were normalized per volume of water. The quantities of gene copy numbers were then determined using standard curves. Gene copy abundances were normalized per gram dry weight of cattle manure or poultry litter after measuring the moisture content of each sample. Finally, the gene copy numbers per gram dry weight were transformed into $\log 10$ values for statistical analysis as they were not normally distributed.

\section{Statistical analysis}

To detect significant differences for fixed effects (manure source and year) on microbial diversity, richness, and evenness, an analysis of variance (ANOVA) was conducted on log transformed data using JMP software [JMP ${ }^{\circledR} 12$ (SAS Institute Inc, 2015)] with sample replicate as a random effect. Probability values less than 0.05 were considered significant. For the contents of nutrients, trace elements, and chemical properties [pH and electrical conductivity (EC)], Fisher's exact test followed by Wilcoxon rank-sum test were performed using gtsummary package (Sjoberg et al., 2020) in R for Windows, v. 4.0.1 (R Core Team, 2020). Redundancy analysis (RDA) was also conducted to understand the relationship between bacterial diversity indices (Chao1, Simpson, and Shannon) and chemical properties (pH, EC, C, N, and major nutrients and trace elements) using the vegan package (Oksanen et al., 2019) in R for Windows, v. 4.0.1 (R Core Team, 2020). Except pH, all the other property variables were log transformed; whereas response variables (Chao1, Simpson, and Shannon indices) were Hellinger transformed, and RDA analysis was run and plotted. To predict bacterial diversity using those environmental variables (physicochemical properties) that contributed for variability in the RDA analysis, linear regression analysis was performed using the ggpubr package (Kassambara, 2020) in R for Windows v. 4.0.1 (R Core Team, 2020).

\section{Results and discussions}

\subsection{Physiochemical properties of cattle manure and poultry litter as a} fertility source

Cattle manure samples had lower total solids (TS), trace elements concentration, and $\mathrm{pH}$, but greater $\mathrm{EC}$ and $\mathrm{C} / \mathrm{N}$ ratio compared to poultry litter (Table 1). These results are consistent with previous studies reporting that the $\mathrm{N}$ content of poultry litter is typically greater than that of cattle manure (Huang et al., 2017). Moreover, the greater TS of poultry litter is likely owing to the use of bedding material during production, which is commonly wood shavings and sawdust (Ashworth et al., 2020). In terms of nutrient composition, poultry litter had greater $\mathrm{NH}_{4}-\mathrm{N}, \mathrm{NO}_{3}-\mathrm{N}, \mathrm{S}, \mathrm{P}, \mathrm{Mg}, \mathrm{Ca}$, and $\mathrm{K}$ compared to cattle manure.

In a comparative study, Zhang et al. (2012) also found lower concentrations of trace elements in cattle manure relative to poultry litter. In contrast to the current findings, high amounts (about $1 \mathrm{~g} \mathrm{~kg}^{-1}$ ) of $\mathrm{Zn}$ and $\mathrm{Cu}$ were reported for cattle manure (Xu et al., 2019). The feed source is predominantly the major determinant for the concentration of nutrients and trace elements in poultry litter and cattle manure (Pagliari et al., 2020; Sager, 2007; Zhang et al., 2012; S1), although the use of pharmaceutical products can also be a source (Sheppard and Sanipelli, 2012; S2). Nevertheless, trace elements content of poultry litter, even in total basis (S1), was far below the concentration limit for the USA (Mortvedt, 1995). However, to reduce possible environmental risks, alternative feed sources could be formulated to minimize the level of heavy metals in manure.

\subsection{Bacterial community composition in cattle manure and poultry litter}

Bacterial community composition varied at both phyla and genera levels in cattle manure and poultry litter (Fig. 1A and B). The following top ten phyla (based on relative abundance) dominated cattle manure bacterial communities: Firmicutes (44.71\%), Bacteroidetes (40.97\%), Bacteria (5.28\%), Actinobacteria (2.47\%), Proteobacteria (2.13\%), Verrucomicrobia (1.35\%), Tenericutes (1.35\%), Cyanobacteria $(0.76 \%)$, Spirochaetes $(0.54 \%)$, and Planctomycetes $(0.44 \%)$ (Fig. 1A). Whereas, based on the relative abundance, eight phyla were dominant in poultry litter: Firmicutes (54.83\%), Actinobacteria (33.00\%), Bacteriodetes (6.86\%), Proteobacteria $(2.90 \%)$, Bacteria $(1.52 \%)$, Thermi $(0.44 \%)$, Chloroflexi $(0.31 \%)$, and Tenericutes $(0.06 \%)$. Bacterial community structure differed between cattle manure and poultry litter $(P<0.05)$.

The three most abundant phyla constituted approximately 91 and $95 \%$ of the overall bacterial community composition in cattle manure and poultry litter, respectively. In particular, Firmicutes dominated microbial composition in both manure sources. Awasthi et al. (2019), Pandey et al. (2018), and Wang et al. (2020) reported similar findings, suggesting Firmicutes are the dominant microorganisms in manure, regardless of the source. According to Zhang et al. (2018), Firmicutes such as Bacillus and Lentibacillus were dominant in poultry litter and include known pathogens and may reach the soil ecosystems following direct application of cattle manure or poultry litter. Several zoonotic bacteria species including Campylobacter jejuni, Escherichia coli, and Listeria monocytogenes have also been detected in fresh cattle manure (Klein et al., 2010).

Bacteroidetes inhabit the environment and gastrointestinal tract (Thomas et al., 2011). They are also found in fresh water and soils and are known to have a functional role in degrading soluble polysaccharides and organic substances of high molecular weight (Naas et al., 2014; Thomas et al., 2011). Because of their importance in 

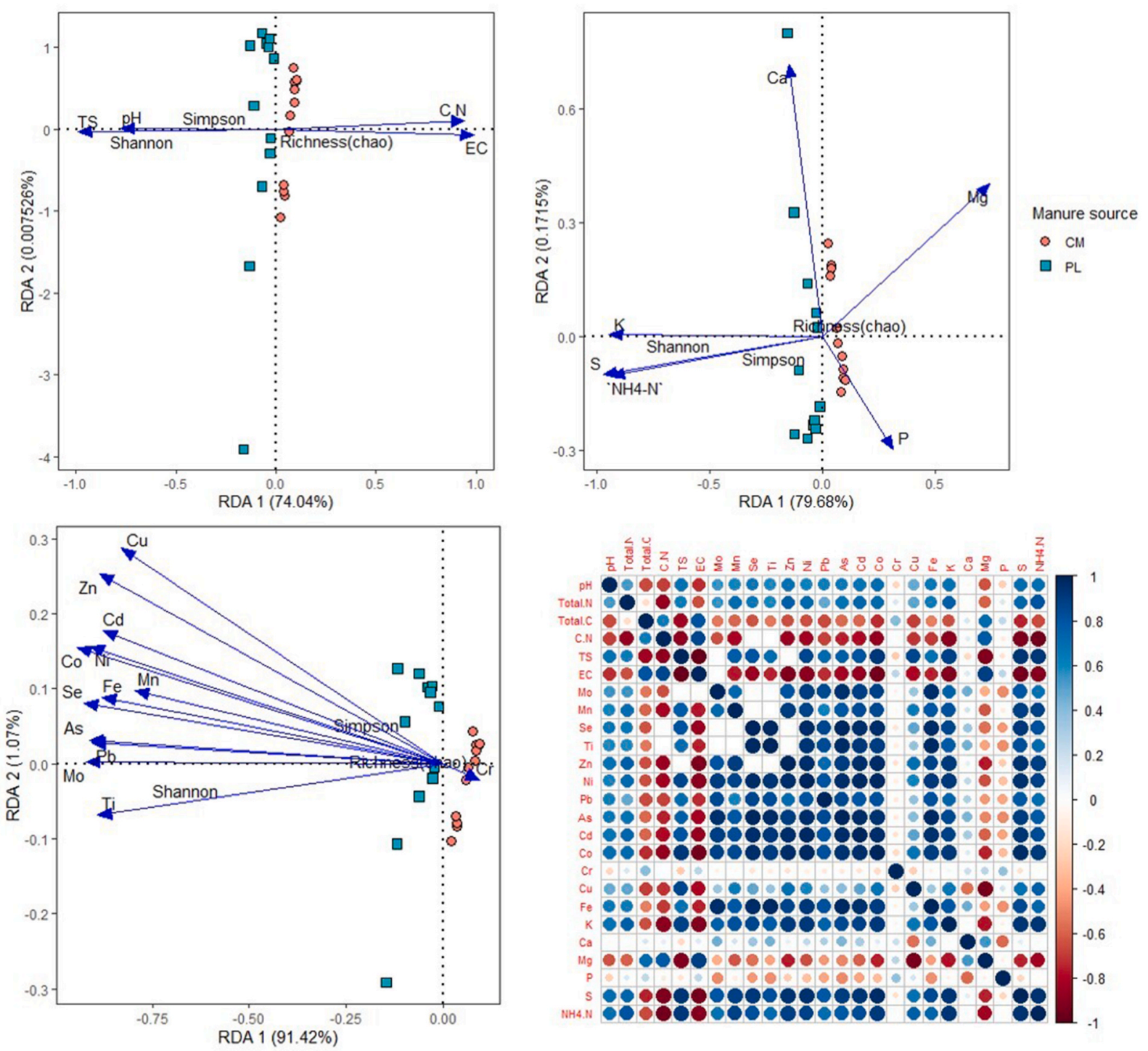

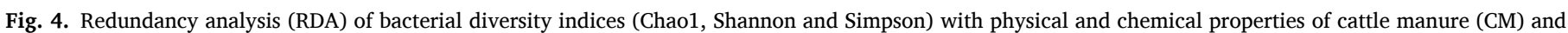

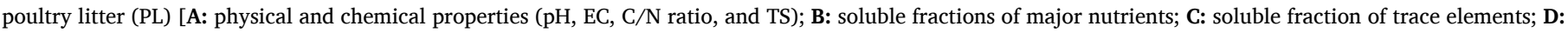

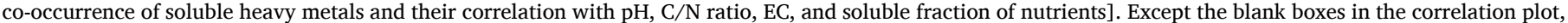
all correlations are significant $(\mathrm{P}<0.05)$.

depolymerizing or degrading organic substances, their abundance in ecosystems might enhance the rate of organic matter turnover that could lead to enhanced $\mathrm{CO}_{2}$ emissions. Moreover, some species of the phyla Myroides, ordoratimimus, and Sphingobacterium spp. are clinically important human pathogens that may also be resistant to antimicrobials (Yang et al., 2014). Given that fresh cattle manure had a higher proportion of Bacteroidetes, its land applications could pose greater environmental risks than poultry litter.

\subsection{Differences in bacterial community structure and its implication on soil microbial structure}

Source of manure affected bacterial structure as evidenced by Chao1, Simpson, and Shannon diversity indices (Table 2). Cattle manure exhibited greater bacterial diversity than poultry litter (Fig. 2). Analysis of beta diversity also demonstrated distinct clustering differences between cattle manure and poultry litter (Fig. 3). The fact that poultry litter is a mixture of poultry manure and bedding (Ashworth et al., 2020), likely influences the physiochemical characteristics of poultry litter that, in turn, affects the bacterial community structure.
Studies comparing microbial structure of manure sources are limited. The current study found a lower alpha bacterial diversity in poultry litter relative to cattle manure. Possible reasons for the lower alpha diversity might be linked to the higher TS content of poultry litter (76\%), (Schimel et al., 1999; Zealand et al., 2018), lower organic C content (Van Horn et al., 2014), and higher soluble trace elements (Tipayno et al., 2018).

5.4. RDA of bacterial diversity constrained by trace elements and physiochemical properties of cattle manure and poultry litter

A comprehensive assessment of physiochemical composition of manure, which included TS, $\mathrm{pH}, \mathrm{EC}$, soluble trace elements, and macronutrients, revealed differences between cattle manure and poultry litter. The RDA analysis illustrated these variables predicted bacterial alpha diversity $(P<0.001)$ with $\mathrm{pH}$, TS, EC, and $\mathrm{C} / \mathrm{N}$ ratio explaining $74 \%$ of the total variation (Fig. $4 \mathrm{~A}$ ). Soluble fractions of available nutrients such as $\mathrm{K}, \mathrm{P}, \mathrm{NH}_{4}-\mathrm{N}$, and $\mathrm{S}$, accounted for $83 \%$ of the total variation (Fig. 4B). Moreover, trace elements, mainly $\mathrm{As}, \mathrm{Ti}$, and $\mathrm{Pb}$, accounted for $90 \%$ of the total variation (Fig. 4C). In addition to the RDA 

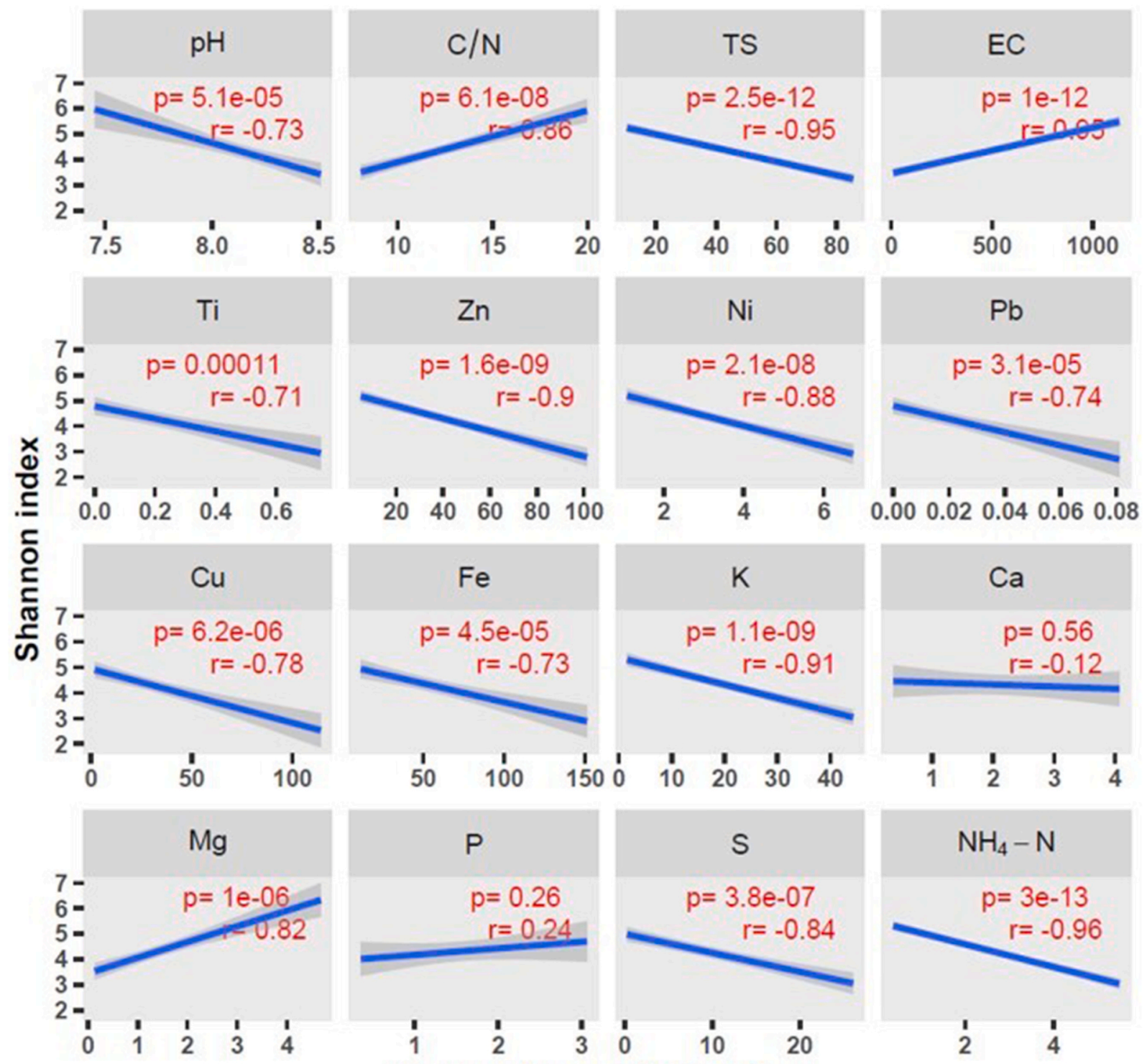

Explanatory variable values

Fig. 5. Linear regression models to predict bacterial diversity (Shannon index as a response variable) using manure physicochemical properties (explanatory variables). Quantities of the chemical contents are on dry matter basis, and the unit for $\mathrm{Ca}, \mathrm{Fe}, \mathrm{K}, \mathrm{P}$ and S is $\mathrm{g} \mathrm{kg}^{-1}$; whereas that of $\mathrm{NH}_{4}-\mathrm{N}$ and the rest of trace elements is in $\mathrm{mg} \mathrm{kg}^{-1}$. The $r$ stands for correlation coefficient..

\section{Table 3}

ANOVA of results testing for differences in quantities of three AMR associated genes by animal source (cattle manure and poultry litter), sampling year (2018 and 2019), and interaction between these two factors.

\begin{tabular}{llll}
\hline Parameter & Factor & Pseudo-F & $P$-value \\
\hline ermB & Animal source & 32.58854 & $3.23 \mathrm{E}-05^{\mathrm{b}}$ \\
& Year & 0.280069 & 0.603921 \\
\multirow{3}{*}{ sulI } & Animal source x Year & 8.065261 & $0.010121^{\mathrm{a}}$ \\
& Animal source & 48.14529 & $3.34 \mathrm{E}-06^{\mathrm{b}}$ \\
& Year & 1.115031 & 0.306675 \\
\multirow{2}{*}{ intlI } & Animal source x Year & 3.590204 & 0.072671 \\
& Animal source & 25.34924 & $0.000122^{\mathrm{b}}$ \\
& Year & 0.499597 & 0.489844 \\
& Animal source x Year & 0.001061 & 0.974335 \\
\hline
\end{tabular}

\footnotetext{
${ }^{\text {a }}$ Statistically significant $(\alpha=0.05)$.

b Statistically significant $(\alpha=0.01)$.
}

results, the correlation analysis showed a strong positive relationship between alpha diversity, C/N ratio, and EC (Fig. 5 and Fig. S1). However, $\mathrm{TS}, \mathrm{pH}$, trace elements and $\mathrm{NH}_{4}-\mathrm{N}$ were negatively correlated with diversity indices.

This study provides insights into the relationships between physiochemical properties and bacterial community structure of manure sources. The cattle manure bacterial community may have benefited from a higher $\mathrm{C} / \mathrm{N}$ ratio, lower TS (14\%), higher EC (940 dS $\mathrm{m}^{-1}$ ) and a slightly alkaline $\mathrm{pH}$. A similar positive correlation between $\mathrm{C} / \mathrm{N}$ ratio and bacteria diversity was also reported by Ge et al. (2010). The C/N ratio has been widely used as an index of stability or maturity of organic residue during composting, as $\mathrm{C}$ substrate having a $\mathrm{C} / \mathrm{N}$ ratio of 16 or larger is not stable for supporting the growth of microorganisms (Macias-Corral et al., 2019). The EC and pH have been widely reported to affect microbial diversity (e.g., Geyer et al., 2013; Ye et al., 2016), with greater EC values in manure indicating nutrient mobility or availability to microbes. Thus, reducing EC could be a strategy to suppress pathogens in cattle manure (Kong et al., 2012). Trace elements can be stimulatory or inhibitory for microorganisms depending on the type 


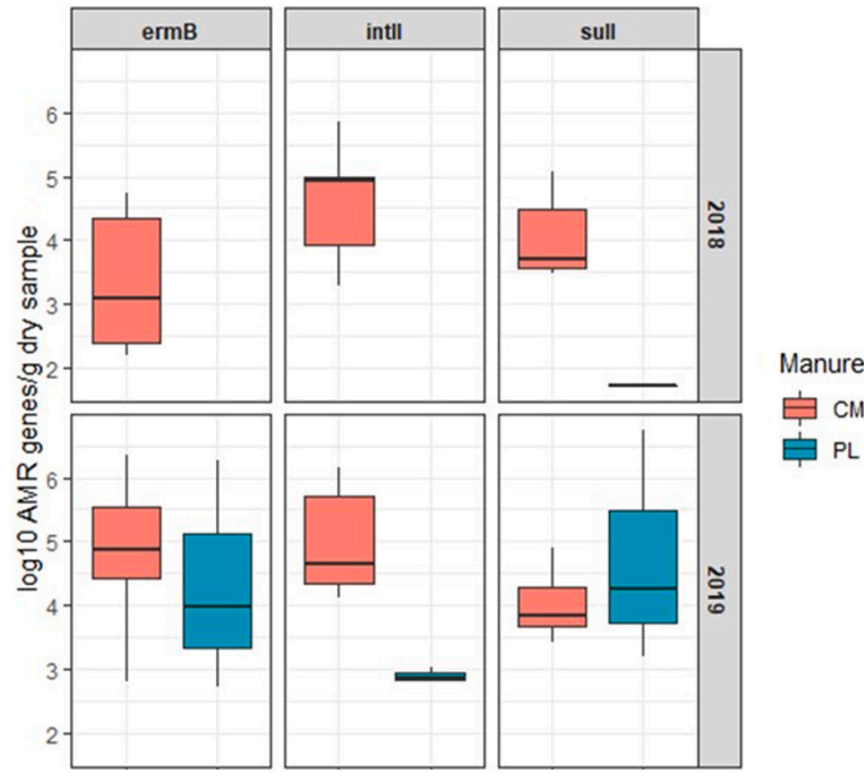

Fig. 6. Box plot of number of AMR genes in cattle manure (CM) and poultry litter (PL) collected in 2018 and 2019.

and concentration level. The strong negative correlations between soluble trace element concentrations and bacterial diversity indices observed in this study may reveal an inhibitory functional role in poultry litter. However, this may be confounded by other factors since the total concentration of heavy metal was too low (Table S1) to be inhibitory or stimulatory (Ding et al., 2017; Mortvedt, 1995) to microorganisms. Moisture is also crucial for microorganisms and inadequate moisture content limits microbial diversity (Maestre et al., 2015). This could also be the case in this study as poultry litter had lower moisture content (higher TS content), which may have resulted in lower bacterial diversity compared to cattle manure.

\subsection{Abundance of AMR genes in cattle manure and poultry litter}

The two-year sampling resulted in AMR gene abundance differences in both cattle manure and poultry litter, with variations in sampling year and source of manure $(P<0.05$, Table 3$)$. Abundance of the two AMR genes (ermB and sull) and the integron intlI were greater in cattle manure in both 2018 and 2019, while they were rarely found in poultry litter samples during 2018 (Fig. 6). The relatively greater abundance of AMR genes of ermB and intlI in cattle manure compared to poultry litter corresponded to higher alpha diversity of the bacterial community. Overall, blactx-m-32 was analyzed but not detected in either manure sources and consequently is not included in subsequent analyses.

The greater abundance of AMR genes in cattle manure compared to poultry litter was not expected. In a study by Xu et al. (2020), more than two fold greater AMR genes were found in poultry manure compared to cattle manure. However, it must be noted that poultry manure rather than poultry litter (chicken manure and the bedding) was evaluated in the study of Xu et al. (2020). Moreover, the very low TS content of cattle manure could underestimate the quantities of AMR genes when estimated on a wet basis compared to solid poultry litter, which has three times less moisture (Table 1). Consistent with these results and knowing that the soil microbial community may shift in response to manure inputs, Yang et al. (2020) found that soils receiving long-term cattle manure deposition yielded greater ermB, sull, and intl gene abundances relative to soils receiving poultry litter. Therefore, using cattle manure for pastureland fertilization may pose a greater risk for AMR dissemination to the environment than poultry litter.
Antimicrobial resistance has existed prior to the advent of antibiotics (Aminov, 2009; Brinkac et al., 2017; Wright, 2007). However, the fecal resistome in cattle manure and poultry litter depends largely on the feed (Liu et al., 2019) and the rate and type of antimicrobials provided to the animals for both therapeutic and non-therapeutic purposes (Barton, 2014; Hughes and Heritage, 2004; Wegener, 2003). Moreover, the quantity of AMR genes released to the environment during application of feces is affected by post-handling and/or management activities. In this study, the bedding that constituted the poultry litter may have increased TS content and suppressed AMR bacteria and genes. This is evidenced by the negative and significant correlation between TS and abundance of bacterial community (Fig. 5). In the USA, air drying is practiced to reduce pathogens in municipal wastewater and Burch et al. (2013) demonstrated reductions of AMR genes in wastewater with this air-drying approach, although sul1 and intI1 were not affected. In the current study, the greater gene copies in poultry litter in 2019 samples also depicts that the in-house piling may not be useful at reducing sulfonamide resistant genes, implying not all AMR genes respond to such treatment. The overall results indicate that increasing TS or aerating manure may be useful to reduce abundance of bacterial community and the chance of release of zoonotic bacteria associated with fresh manure use.

\section{Conclusions}

Fresh cattle manure deposition during grazing may increase agronomic productivity, as well as alter soil microbial structure and may be a source of AMR genes entering soils. In contrast, poultry litter applications have greater advantages not only in terms of nutrient supply, but also environmental risks associated with disseminating AMR genes to the environment based on the operations evaluated. The strong link between bacterial diversity and physiochemical properties of both cattle manure and poultry litter adds novel insights into the field of animal manure management. A reduced $\mathrm{C} / \mathrm{N}$ ratio and increased TS may be drivers for low bacterial alpha diversity and AMR gene abundance. Further work is needed to formally annotate antibiotic use and subsequent AMR gene presence in various manure sources, as well as the potential for alternatives to antibiotics and manure composting to minimize the spread and dissemination of AMR genes to soil and water bodies.

\section{Funding}

This research was funded by the United States Department of Agriculture, Agricultural Research Service Funding Opportunities in Antimicrobial Resistance.

\section{Author contributions}

Conceptualization, A.A.; methodology, A.A., Y.Y.; formal analysis, B. G., Y.Y.; data curation, A.A., Y.Y., S.R.; writing-original draft preparation, B.G., A.A., Y.Y.; writing-review and editing, M.S., P.M., S.R., G. C., E.P., S.C. All authors have read and agreed to the published version of the manuscript.

\section{Declaration of competing interest}

The authors declare that they have no known conflict of interest or personal relationships that could have appeared to influence the work reported in this paper.

\section{Acknowledgements}

Authors are grateful to Steve Haller and Brent Woolley with the USDA-ARS in Booneville for providing maintenance of experimental plots and assisting with sample collection. Mention of trade names or 
commercial products in this publication is solely for the purpose of providing specific information and does not imply recommendation or endorsement by the U.S. Department of Agriculture.

\section{Appendix A. Supplementary data}

Supplementary data to this article can be found online at https://doi. org/10.1016/j.envres.2021.111011.

\section{References}

Aminov, R.I., 2009. The role of antibiotics and antibiotic resistance in nature. Environ Microbiol. 11, 2970-2988. https://doi.org/10.1111/j.1462-2920.2009.01972.x.

APHA, 1995. Standard Methods for the Examination of Water and Wastewater, nineteenth ed. Public Health Assoc, Washington, DC, USA.

Ashworth, A.J., Chastain, J.P., Moore, P.A., 2020. Nutrient Characteristics of Poultry Manure and Litter 63-87. https://doi.org/10.2134/asaspecpub67.c5.

Awasthi, M.K., Chen, H., Liu, T., Awasthi, S.K., Wang, Q., Ren, X., Duan, Y., Zhang, Z. 2019. Respond of clay amendment in chicken manure composts to understand the antibiotic resistant bacterial diversity and its correlation with physiochemicalparameters. J. Clean. Prod. 236, 117715. https://doi.org/10.1016/j. jclepro.2019.117715.

Barton, M.D., 2014. Antibiotic Use in Animal Feed and its Impact on Human Health. https://doi.org/10.1079/095442200108729106.

Blazejewski, T., Hsing-I, H., Harris, H.W., 2019. Synthetic sequence entanglement augments stability and containment of genetic information in cells. Science $595-598$.

Brinkac, L., Voorhies, A., Gomez, A., Nelson, K.E., 2017. The threat of antimicrobial resistance on the human microbiome. Microb. Ecol. 74, 1001-1008. https://doi.org/ 10.1007/s00248-017-0985-z.

Burch, T.R., Sadowsky, M.J., Lapara, T.M., 2013. Air-drying beds reduce the quantities of antibiotic resistance genes and class 1 integrons in residual municipal wastewater solids. Environ. Sci. Technol. 47, 9965-9971. https://doi.org/10.1021/es4024749.

Caporaso, J.G., Lauber, C.L., Walters, W.A., Berg-Lyons, D., Lozupone, C.A., Turnbaugh, P.J., Fierer, N., Knight, R., 2011. Global patterns of 16S rRNA diversity at a depth of millions of sequences per sample. Proc. Natl. Acad. Sci. U.S.A. 108, 4516-4522. https://doi.org/10.1073/pnas.1000080107.

Ding, Z., Wu, J., You, A., Huang, B., Cao, C., 2017. Effects of heavy metals on soil microbial community structure and diversity in the rice (Oryza sativa L. subsp. Japonica, Food Crops Institute of Jiangsu Academy of Agricultural Sciences) rhizosphere. Soil Sci. Plant Nutr. 63, 75-83. https://doi.org/10.1080/ 00380768.2016.1247385.

Durso, L.M., Cook, K.L., 2014. Impacts of antibiotic use in agriculture: what are the benefits and risks? Curr. Opin. Microbiol. 19, 37-44.

Durso, L.M., Miller, D.N., Wienhold, B.J., 2012. Distribution and quantification of antibiotic resistant genes and bacteria across agricultural and non-agricultural metagenomes. PloS One. https://doi.org/10.1371/journal.pone.0048325.

Ge, Y., Chen, C., Xu, Z., Eldridge, S.M., Chan, K.Y., He, Y., He, J.Z., 2010. Carbon/ nitrogen ratio as a major factor for predicting the effects of organic wastes on soil bacterial communities assessed by DNA-based molecular techniques. Environ. Sci. Pollut. Res. 17, 807-815. https://doi.org/10.1007/s11356-009-0185-6.

Geyer, K.M., Altrichter, A.E., Van Horn, D.J., Takacs-Vesbach, C.D., Gooseff, M.N., Barrett, J.E., 2013. Environmental controls over bacterial communities in polar desert soils. Ecosphere 4, 1-17. https://doi.org/10.1890/ES13-00048.1.

Giles, C.D., Cade-Menun, B.J., 2014. Applied manure and nutrient chemistry for sustainable agriculture and environment. In: He, Z., Zhang, H. (Eds.), Applied Manure and Nutrient Chemistry for Sustainable Agriculture and Environment. Springer Netherlands, Dordrecht, pp. 1-379. https://doi.org/10.1007/978-94-0178807-6.

Gurmessa, B., Pedretti, E.F., Cocco, S., Cardelli, V., Corti, G., 2020. Manure anaerobic digestion effects and the role of pre- and post-treatments on veterinary antibiotics and antibiotic resistance genes removal efficiency. Sci. Total Environ. 721, 137532 https://doi.org/10.1016/j.scitotenv.2020.137532.

Huang, J., Yu, Z., Gao, H., Yan, X., Chang, J., Wang, C., Hu, J., Zhang, L., 2017. Chemical structures and characteristics of animal manures and composts during composting and assessment of maturity indices. PloS One 12, 1-16. https://doi.org/10.1371/ journal.pone.0178110.

Hughes, P., Heritage, J., 2004. Antibiotic growth-promoters in food animals. In assessing quality and safety of animal feeds. Assess. Qual. Saf. Anim. Feed. 129-153.

Kassambara, A., 2020. Ggpubr: "Ggplot2" Based Publication Ready Plots. R package version 0.4.0. https://CRAN.R-project.org/package=ggpubr.

Klein, M., Brown, L., Tucker, R.W., Ashbolt, N.J., Stuetz, R.M., Roser, D.J., 2010. Diversity and abundance of zoonotic pathogens and indicators in manures of feedlot cattle in Australia. Appl. Environ. Microbiol. 76, 6947-6950. https://doi.org/ 10.1128/AEM.01095-10.

Kong, P., Lea-Cox, J.D., Hong, C.X., 2012. Effect of electrical conductivity on survival of Phytophthora alni, P. kernoviae and P. ramorum in a simulated aquatic environment. Plant Pathol. 61, 1179-1186. https://doi.org/10.1111/j.13653059.2012.02614.x.

Kozich, J.J., Westcott, S.L., Baxter, N.T., Highlander, S.K., Schloss, P.D., 2013. Development of a dual-index sequencing strategy and curation pipeline for analyzing amplicon sequence data on the miseq illumina sequencing platform. Appl. Environ. Microbiol. 79, 5112-5120. https://doi.org/10.1128/AEM.01043-13.
Liu, J., Taft, D.H., Maldonado-Gomez, M.X., Johnson, D., Treiber, M.L., Lemay, D.G., DePeters, E.J., Mills, D.A., 2019. The fecal resistome of dairy cattle is associated with diet during nursing. Nat. Commun. 10 https://doi.org/10.1038/s41467-019-12111-

Macias-Corral, M.A., Cueto-Wong, J.A., Morán-Martínez, J., Reynoso-Cuevas, L., 2019. Effect of different initial C/N ratio of cow manure and straw on microbial quality of compost. Int. J. Recycl. Org. Waste Agric. 8, 357-365. https://doi.org/10.1007/ s40093-019-00308-5.

Maestre, F.T., Delgado-Baquerizo, M., Jeffries, T.C., Eldridge, D.J., Ochoa, V., Gozalo, B., Quero, J.L., García-Gómez, M., Gallardo, A., Ulrich, W., Bowker, M.A., Arredondo, T., Barraza-Zepeda, C., Bran, D., Florentino, A., Gaitán, J., Gutiérrez, J. R., Huber-Sannwald, E., Jankju, M., Mau, R.L., Miriti, M., Naseri, K., Ospina, A., Stavi, I., Wang, D., Woods, N.N., Yuan, X., Zaady, E., Singh, B.K., 2015. Increasing aridity reduces soil microbial diversity and abundance in global drylands. Proc. Natl. Acad. Sci. U.S.A. 112, 15684-15689. https://doi.org/10.1073/pnas.1516684112.

Mortvedt, J.J., 1995. Heavy metal contaminants in inorganic and organic fertilizers. Fert. Res. 43, 55-61. https://doi.org/10.1007/BF00747683.

Naas, A.E., Mackenzie, A.K., Mravec, J., Schückel, J., Willats, W.G.T., Eijsink, V.G.H., Pope, P.B., 2014. Do rumen Bacteroidetes utilize an alternative mechanism for cellulose degradation? mBio 5, 4-9. https://doi.org/10.1128/mBio.01401-14.

Oksanen, A.J., Blanchet, F.G., Friendly, M., Kindt, R., Legendre, P., Mcglinn, D., Minchin, P.R., Hara, R.B.O., Simpson, G.L., Solymos, P., Stevens, M.H.H., Szoecs, E., 2019. vegan: Community Ecology Package. R package version 2.5-6. https://CRAN.Rproject.org/package= vegan'.

Pagliari, P.H., Wilson, M., Waldrip, H.M., He, Z., 2020. Nitrogen and phosphorus characteristics of beef and dairy manure. Z.H.. In: Waldrip, Heidi M., Pagliari, Paulo H. (Eds.), Animal Manure: Production, Characteristics, Environmental Concerns and Management, pp. 45-62. https://doi.org/10.2134/asaspecpub67.c4.

Pandey, P., Chiu, C., Miao, M., Wang, Y., Settles, M., Del Rio, N.S., Castillo, A., Souza, A., Pereira, R., Jeannotte, R., 2018. 16S rRNA analysis of diversity of manure microbial community in dairy farm environment. PloS One 13, 1-18. https://doi.org/10.1371/ journal.pone.0190126.

Pilon, C., Moore, P.A., Pote, D.H., Martin, J.W., Owens, P.R., Ashworth, A.J., Miller, D. M., DeLaune, P.B., 2019. Grazing management and buffer strip impact on nitrogen runoff from pastures fertilized with poultry litter. J. Environ. Qual. 48, 297-304. https://doi.org/10.2134/jeq2018.04.0159.

Qian, X., Gu, J., Sun, W., Wang, X.J., Su, J.Q., Stedfeld, R., 2018. Diversity, abundance, and persistence of antibiotic resistance genes in various types of animal manure following industrial composting. J. Hazard Mater. 344, 716-722. https://doi.org/ 10.1016/j.jhazmat.2017.11.020.

R Core Team, 2020. R: A Language and Environment for Statistical Computing. R Foundation for Statistical Computing, Vienna, Austria. https://www.R-project.org/.

Sager, M., 2007. Trace and nutrient elements in manure, dung and compost samples in Austria. Soil Biol. Biochem. 39, 1383-1390. https://doi.org/10.1016/j. soilbio.2006.12.015.

SAS Institute Inc, 2015. Using JMP ${ }^{\circledR}$ 12. SAS Institute Inc, Cary, NY.

Schimel, J.P., Gulledge, J.M., Clein-Curley, J.S., Lindstrom, J.E., Braddock, J.F., 1999. Moisture effects on microbial activity and community structure in decomposing birch litter in the Alaskan taiga. Soil Biol. Biochem. 31, 831-838. https://doi.org/ 10.1016/S0038-0717(98)00182-5.

Self-Davis, M.L., Moore, P.A.J., 2000. Methods of phosphorus analysis for soils, sediments, residuals, and waters. In: Pierzynski, G.M. (Ed.), In Methods of Phosphorus Analysis for Soils, Sediments, Residuals, and Water; Southern Cooperative Series Bulletin No. 396, SERA-IEG 17. North Carolina State University, Raleigh, NC, USA, pp. 74-77.

Sheppard, S.C., Sanipelli, B., 2012. Trace elements in feed, manure, and manured soils. J. Environ. Qual. 41, 1846-1856. https://doi.org/10.2134/jeq2012.0133.

Sjoberg, D.D., Hannum, M., Karissa, W., Zabor, E.C., 2020. Gtsummary: PresentationReady Data Summary and Analytic Result Tables. R package version 1.3.2.

Thomas, F., Hehemann, J.H., Rebuffet, E., Czjzek, M., Michel, G., 2011. Environmental and gut Bacteroidetes: the food connection. Front. Microbiol. 2, 1-16. https://doi. org/10.3389/fmicb.2011.00093.

Tipayno, S.C., Truu, J., Samaddar, S., Truu, M., Preem, J.K., Oopkaup, K., Espenberg, M., Chatterjee, P., Kang, Y., Kim, K., Sa, T., 2018. The bacterial community structure and functional profile in the heavy metal contaminated paddy soils, surrounding a nonferrous smelter in South Korea. Ecol. Evol. 8, 6157-6168. https://doi.org/ 10.1002/ece3.4170.

USEPA Method 351.2, 1983. Methods for Chemical Analysis of Water and Wastes (OH).

Van Horn, D.J., Okie, J.G., Buelow, H.N., Gooseff, M.N., Barrett, J.E., Takacs-Vesbach, C. D., 2014. Soil microbial responses to increased moisture and organic resources along a salinity gradient in a polar desert. Appl. Environ. Microbiol. 80, 3034-3043. https://doi.org/10.1128/AEM.03414-13.

Wang, N., Guo, X., Yan, Z., Wang, W., Chen, B., Ge, F., Ye, B., 2016. A comprehensive analysis on spread and distribution characteristic of antibiotic resistance genes in livestock farms of Southeastern China. PloS One 11, 1-14. https://doi.org/10.1371/ journal.pone.0156889.

Wang, Y., Yuan, T., Zhang, Z., Lei, Z., Shimizu, K., 2020. Improved lignocellulose degradation prior to semi-dry anaerobic digestion of dairy manure via potassium permanganate treatment. Bioresour. Technol. Reports 11, 100462. https://doi.org/ 10.1016/j.biteb.2020.100462.

Wegener, H.C., 2003. Antibiotics in animal feed and their role in resistance development. Curr. Opin. Microbiol. 6, 439-445. https://doi.org/10.1016/j.mib.2003.09.009.

Whalen, J.K., Chang, C., Clayton, G.W., Carefoot, J.P., 2000. Cattle manure amendments can increase the $\mathrm{pH}$ of acid soils. Soil Sci. Soc. Am. J. 64, 962-966. https://doi.org/ $10.2136 /$ sssaj2000.643962x. 
Wright, G.D., 2007. The antibiotic resistome: the nexus of chemical and genetic diversity. Nat. Rev. Microbiol. 5, 175-186. https://doi.org/10.1038/nrmicro1614.

Xie, W.Y., Shen, Q., Zhao, F.J., 2018. Antibiotics and antibiotic resistance from animal manures to soil: a review. Eur. J. Soil Sci. 69, 181-195. https://doi.org/10.1111/ ejss.12494.

Xu, Y., Li, H., Shi, R., Lv, J., Li, B., Yang, F., Zheng, X., Xu, J., 2020. Antibiotic resistance genes in different animal manures and their derived organic fertilizer. Environ. Sci. Eur. 32 https://doi.org/10.1186/s12302-020-00381-y.

Xu, Y., Li, J., Zhang, X., Wang, L., Xu, X., Xu, L., Gong, H., Xie, H., Li, F., 2019. Data integration analysis: heavy metal pollution in China's large-scale cattle rearing and reduction potential in manure utilization. J. Clean. Prod. 232, 308-317. https://doi. org/10.1016/j.jclepro.2019.05.337.

Xu, Z., Zhang, T., Wang, S., Wang, Z., 2020. Soil pH and C/N ratio determines spatial variations in soil microbial communities and enzymatic activities of the agricultural ecosystems in Northeast China: jilin Province case. Appl. Soil Ecol. 155, 103629. https://doi.org/10.1016/j.apsoil.2020.103629.

Yang, Y., Ashworth, A.J., DeBruyn, J.M., Willett, C., Durso, L.M., Cook, K.L., Moore, P., Owens, P.R., 2019. Soil biodiversity is driven by long-term pasture management, poultry litter, and cattle manure inputs. PeerJ_Life \& Environment, e7839. https:// doi.org/10.7717/peerj.7839.

Yang, Y., Ashworth, A.J., DeBruyn, J., M Durso, L., Savin, M., Cook, K., Moore Jr., P.A., Owens, P.R., 2020. Antimicrobial resistant gene prevalence in soils due to animal manure deposition and long-term pasture management. PeerJ 8, e10258. https:// doi.org/10.7717/peerj.10258.

Yang, Q., Ren, S., Niu, T., Guo, Y., Qi, S., Han, X., Liu, D., Pan, F., 2014. Distribution of antibiotic-resistant bacteria in chicken manure and manure-fertilized vegetables.
Environ. Sci. Pollut. Res. 21, 1231-1241. https://doi.org/10.1007/s11356-0131994-1.

Ye, M., Sun, M., Feng, Y., Wan, J., Xie, S., Tian, D., 2016. Effect of biochar amendment on the control of soil sulfonamides, antibiotic-resistant bacteria , and gene enrichment in lettuce tissues. J. Hazard Mater. 309, 219-227. https://doi.org/10.1016/j. jhazmat.2015.10.074.

Zarcinas, B.A., Cartwright, B., Spouncer, L.R., 1987. Communications in Soil Science and Plant Analysis Nitric acid digestion and multi - element analysis of plant material by inductively coupled plasma spectrometry. Commun. Soil Sci. Plant Anal. 18, 131-146. https://doi.org/10.1080/00103628709367806.

Zealand, A.M., Mei, R., Papachristodoulou, P., Roskilly, A.P., Liu, W.T., Graham, D.W., 2018. Microbial community composition and diversity in rice straw digestion bioreactors with and without dairy manure. Appl. Microbiol. Biotechnol. 102, 8599-8612. https://doi.org/10.1007/s00253-018-9243-7.

Zhang, F., Li, Y., Yang, M., Li, W., 2012. Content of heavy metals in animal feeds and manures from farms of different scales in Northeast China. Int. J. Environ. Res. Publ. Health 9, 2658-2668. https://doi.org/10.3390/ijerph9082658.

Zhou, Z., Yao, H., 2020. Effects of composting different types of organic fertilizer on the microbial community structure and antibiotic resistance genes. Microorganisms 8 , 1-20. https://doi.org/10.3390/microorganisms8020268.

Ziemer, C.J., Bonner, J.M., Cole, D., Vinjé, J., Constantini, V., Goyal, S., Gramer, M., Mackie, R., Meng, X.J., Myers, G., Saif, L.J., 2010. Fate and transport of zoonotic, bacterial, viral, and parasitic pathogens during swine manure treatment, storage, and land application. J. Anim. Sci. 88 https://doi.org/10.2527/jas.2009-2331. 